\title{
NOTA/NOTE
}

\section{Primer registro del pepino de mar garra de león Euapta godeffroyi Semper, 1868 (Holothuroidea: Apodida: Synaptidae) en la isla Gorgona, Pacífico colombiano}

\section{First record of the lion's paw sea-cucumber Euapta godeffroyi Semper, 1868 (Holothuroidea: Apodida: Synaptidae) in Gorgona Island, Colombian Pacific}

\author{
Edgardo Londoño-Cruz \\ (D) $0000-0001-5762-9430$ \\ Grupo de Investigación en Ecosistemas Rocosos Intermareales y Submareales Someros (Lithos), Departamento de Biología, Universidad del Valle, Cali, \\ Colombia.edgardo.londono@correounivalle.edu.co
}

\section{RESUMEN}

$\mathrm{L}$ os holotúridos corresponden a $20-25 \%$ de todas las especies conocidas de equinodermos. En el Pacífico colombiano se han registrado 34 especies, de las cuales 11 lo han sido en la isla Gorgona. Este es el primer registro del pepino de mar garra de león

Euapta godeffroyi en la isla. El espécimen fue recolectado mediante buceo autónomo en el submareal del parche coralino conocido localmente como El Arrecifito del Muelle, a una profundidad aproximada de $2 \mathrm{~m}$. Tenía una longitud aproximada de $80 \mathrm{~cm}$ y entre 2 y $3 \mathrm{~cm}$ de diámetro. Los osículos de la pared del cuerpo corresponden básicamente a anclas y a placas de anclas; estas últimas presentan pequeñas ramificaciones en la base del eje central. El presente registro llena un vacío en la distribución de esta especie en el Pacífico Oriental Tropical.

PALABRAS CLAVE: distribución, arrecife de coral, biodiversidad, equinodermos

\section{ABSTRACT}

$\mathrm{H}$

olothurians correspond to $20-25 \%$ of all known species of echinoderms. In the Colombian Pacific, 34 species have been recorded, of which 11 have been recorded on Gorgona Island. This is the first report of the lion's paw sea-cucumber Euapta godeffroyi on the island. The specimen was collected by scuba diving in the subtidal coralline patch known locally as El Arrecifito del Muelle, at a depth of approximately $2 \mathrm{~m}$. It was about $80 \mathrm{~cm}$ long and between 2 and $3 \mathrm{~cm}$ in diameter. The ossicles of the body wall basically correspond to anchors and anchor plates; the latter have tiny ramifications at the base of the central axis. The present report fills a gap in the distribution of this species for the Tropical Eastern Pacific.

KEYWORDS: distribution, coral reef, biodiversity, echinoderms 
Los equinodermos son miembros muy importantes de la comunidad bentónica. Son habitantes comunes de todos los tipos de ambientes marinos y pueden ser encontrados a todas las profundidades, siendo la fauna dominante de algunos ambientes (Borrero-Pérez et al., 2012; Alvarado and Solís-Marín, 2013). El número de especies vivas en el filo Echinodermata está alrededor de 7000 dependiendo de la fuente: 7550 (Zhang, 2013), 6950 (Pawson, 2007) y 6828 (Roskov et al., 2019). Dentro de este filo, los pepinos marinos (clase Holothuroidea) comprenden $20-25 \%$ de todas las especies aceptadas, lo que los convierte en la tercera clase con más riqueza (Figura 1). Existen 124 especies de equinodermos registrados para la costa del Pacífico colombiano (BenavidesSerrato et al., 2013), de los cuales 34 (i. e. $27 \%$ ) son holotúridos. Para la isla Gorgona, Neira y Cantera (2005) registraron un total de 39 especies de equinodermos, en los cuales había 11 especies de pepinos de mar (i. e. $28 \%$ ). Estos números, comparados con los registros para el Caribe colombiano, son pálidos. Lo anterior puede deberse a un patrón real o a un menor esfuerzo de investigación en la costa Pacífica de Colombia. Recientemente, Muñoz y Londoño-Cruz (2016) y Londoño-Cruz et al. (2018) registraron la presencia de dos especies de equinoideos en la isla Gorgona, lo que incrementa el número de especies conocidas para esta área protegida a 41 .

Dado lo anterior, es altamente probable que el número de especies de equinodermos y, especialmente, la de los pepinos de mar en el Pacífico colombiano sea más alto. Sin embargo, el poco esfuerzo puesto en la investigación de este grupo y la ausencia de especialistas, reflejado en inventarios incompletos y en la falta de literatura apropiada para la identificación de estos animales en el Pacífico colombiano, abre la oportunidad para descubrimientos (e. g. Borrero-Pérez y VanegasGonzález, 2019) y nuevos registros. Este puede ser el caso de Euapta godeffroyi, una especie que, a pesar de ser común, no ha sido registrada oficialmente para el Parque Nacional Natural Gorgona. De ahí que este trabajo documente por primera vez la presencia del pepino de mar garra de león $E$. godeffroyi en la isla Gorgona y proporcione la primera localidad conocida y confirmada en la costa Pacífica de Colombia.

El espécimen fue recolectado manualmente con una red de buceo el 7 de marzo de 2011 alrededor de las $20 \mathrm{~h}$ a una profundidad aproximada de 2-3 $\mathrm{m}$ en el parche arrecifal localmente conocido como El Arrecifito del Muelle (2,9592 $\mathrm{N}, \mathrm{y} 78,1447^{\circ} \mathrm{W}$ ), en la isla Gorgona. Este parche, como todos los arrecifes en la isla, es dominado por corales del género Pocillopora. Después de la recolección, el pepino de mar fue puesto en una bandeja plástica con agua de mar para permitir
The echinoderms are very important members of bottom communities. They are common inhabitants of all sorts of marine environments and can be found at all depths, being the dominant fauna in some environments (BorreroPérez et al., 2012; Alvarado and Solís-Marín, 2013). The number of living species in the phylum Echinodermata revolves around 7000 depending on the source: 7550 (Zhang, 2013), 6950 (Pawson, 2007), and 6828 (Roskov et al., 2019). Within this phylum, the sea-cucumbers (class Holothuroidea) comprise $20-25 \%$ of all accepted species, becoming the third richest class (Figure 1). There are 124 echinoderm species reported for the Pacific coast of Colombia (Benavides-Serrato et al., 2013), of which 34 (i.e. $\sim 27 \%$ ) are holothurians. For Gorgona Island, Neira and Cantera (2005) reported a total of 39 species of echinoderms, in which there were 11 species of seacucumbers (i.e. $28 \%$ ). These numbers, as compared to the reports for the Colombian Caribbean, are pale. It can be due to a real pattern or to less research effort on the Pacific coast of Colombia. Recently, Muñoz and Londoño-Cruz (2016) and Londoño-Cruz et al. (2018) reported the presence of two species of echinoids in Gorgona Island, increasing the number of known species to 41 for this protected area.

Given the above, it is highly probable that the number of species of echinoderms and especially that of sea-cucumbers in the Colombian Pacific is higher. However, the little effort put in researching this group and the lack of specialists reflects in incomplete inventories and the absence of appropriate literature for the identification of these animals in the Colombian Pacific, opening the opportunity for discoveries (e.g. Borrero-Pérez and Vanegas-González, 2019) and new reports. This might be the case of Euapta godeffroyi, a species that albeit being common, has not been officially reported in the Gorgona National Natural Park. Hence, this paper documents for the first time the presence of the lion's paw sea-cucumber E. godeffroyi in Gorgona Island and gives the first known and confirmed locality in the Pacific coast of Colombia.

The specimen was collected manually using a diving net, on March 7, 2011, around $20 \mathrm{~h}$ at a depth of approximately $2-3 \mathrm{~m}$ in the patch reef locally known as El Arrecifito del Muelle $\left(2,9592^{\circ} \mathrm{N}\right.$, and $\left.78,1447^{\circ} \mathrm{W}\right)$ in Gorgona Island. This patch, like all the reefs in the Island, is dominated by corals of the genus Pocillopora. After collection, the sea-cucumber was placed on a plastic tray filled with seawater to allow it to relax and die; subsequently, it was fixed in $70 \%$ ethanol. The specimen was deposited and 


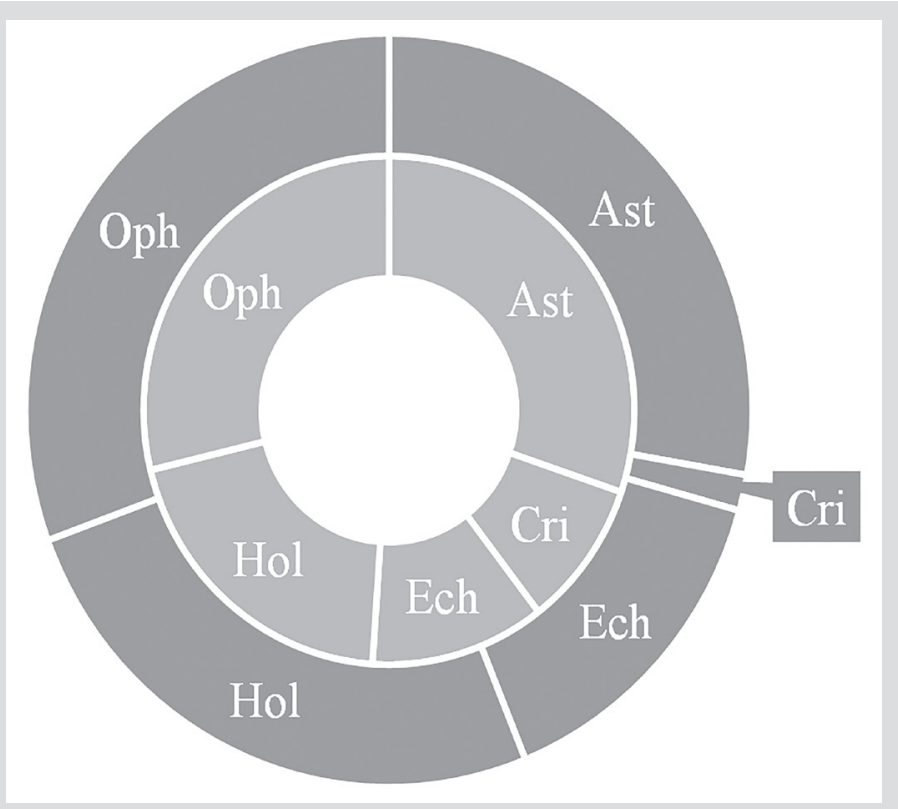

Figura 1. Proporción de riqueza de especies entre las diferentes clases de equiodermos (Ast: Asteroidea, Cri: Crinoidea, Ech: Echinoidea, Hol: Holothuroidea y Oph: Ophiuroidea), de acuerdo con Roskov et al. (2019) [anillo externo] y Pawson (2007) [anillo interno].
Figure 1. Proportion of species richness between the different classes of echinoderms (Ast: Asteroidea, Cri: Crinoidea, Ech: Echinoidea, Hol: Holothuroidea, and Oph: Ophiuroidea), according to Roskov et al. (2019) [outer ring] and Pawson (2007) [inner ring]. que se relajara y muriera; posteriormente, fue fijado en etanol al $70 \%$. El espécimen fue depositado y rotulado con el código CRE11003 en la Colección de Referencia de Biología Marina (Departamento de Biología, Universidad del Valle, Cali, Colombia).

Se compararon fotografías de campo de otros especímenes de la misma especie y la anatomía externa del individuo recolectado con registros y fotografías en guías de campo (Brusca, 1980; Kerstitch and Bertsch, 2007), registros regionales (Granja-Fernández et al., 2013) y la descripción original (Semper, 1868). En adición, se tomaron muestras de tejido y se trataron con hipoclorito de sodio $(\mathrm{NaOCl})$ para digerir el tejido blando y liberar los osículos, los cuales fueron montados, observados y fotografiados bajo microscopía de luz (10 y 40X).

De acuerdo con WoRMS (2020), la siguiente es la taxonomía actual, válida y aceptada del espécimen recolectado en la isla Gorgona:

Filo Echinodermata Bruguière, 1791 [ex Klein, 1734]

Subfilo Echinozoa Haeckel, 1895

Clase Holothuroidea Selenka, 1867

Orden Apodida Brandt, 1835

Familia Synaptidae Burmeister, 1837 tagged with the code CRE11003 in the Reference Collection of Marine Biology (Biology Department, Universidad del Valle, Cali, Colombia).

Field photographs of other specimens of this species and the external anatomy of the collected individual were compared with reports and photographs in field guides (Brusca, 1980; Kerstitch and Bertsch, 2007), regional reports (Granja-Fernández et al., 2013), and the original description (Semper, 1868). Also, tissue samples were taken and treated with sodium hypochlorite $(\mathrm{NaOCl})$ to digest the soft tissue and free the ossicles, which were mounted, observed, and photographed under light microscopy (10 and 40X).

According to WoRMS (2020), the following is the current, valid, and accepted taxonomy for the specimen collected at Gorgona Island:

Phylum Echinodermata Bruguière, 1791 [ex Klein, 1734]

Subphylum Echinozoa Haeckel, 1895

Class Holothuroidea Selenka, 1867

Order Apodida Brandt, 1835

Family Synaptidae Burmeister, 1837

Genus Euapta Östergren, 1898

Species Euapta godeffroyi (Semper, 1868) 


\section{Género Euapta Östergren, 1898}

Especie Euapta godeffroyi (Semper, 1868)

Tamaño: aproximadamente $80 \mathrm{~cm}$ de longitud y entre 2 y 3 $\mathrm{cm}$ de diámetro.

Hábitat: fondo de arena y cascajo coralino junto a parche coralino de Pocillopora sp.

Localidad y sitio de colecta: Parque Nacional Natural Gorgona, El Arrecifito del Muelle.

El espécimen recolectado (junto con los observados en campo) mostró el color típico y el patrón de coloración registrado por otros autores (Semper, 1868; Granja-Fernández et al., 2013): cuerpo gris-pardusco con dos líneas amarillas visibles y un centro pardo sobre la región dorsal (Figura 2A). Esas líneas se extienden desde la región oral, donde están más intensamente coloreadas, hasta la parte aboral. Parece, sin embargo, que la intensidad de la coloración es variable en el nivel intraespecífico. Los tentáculos, que son usados para la alimentación, son de color cremoso y pinnados. Bajo condiciones de estrés o peligro, se retraen en el cuerpo (Figura 2B y 2C). El cuerpo de E. godeffroyi es extremadamente blando y flexible, lo que le permite contraer o expandir su longitud y diámetro varias veces. De acuerdo con Brusca (1980), un espécimen de alrededor de $30 \mathrm{~cm}$ de longitud puede alcanzar $120 \mathrm{~cm}$ cuando está completamente relajado y extendido. Finalmente, la superficie del cuerpo presenta varias hileras de formaciones en forma de bolsas, dando la apariencia de una mazorca (Figura 2).

Los componentes esqueléticos de la pared del cuerpo son principalmente osículos con forma de ancla y pequeñas ramificaciones en la base del eje central y osículos con forma de placa, grandes perforaciones (Figura 3A, 3B y 3C) y gránulos miliares. Estos tipos de osículos ya han sido registrados en diferentes especies de la familia Synaptidae (Hendler et al., 1995; Borrero-Pérez et al., 2012). Dos tipos de osículos más fueron observados: uno con forma de ancla y extremos suaves y agudos (una etapa temprana de las anclas) y otro con forma de varilla y extremos bifurcados arborescentes (Figura 3D y 3E). Es importante anotar que las anclas (completamente desarrolladas o en estadios tempranos) y las placas estaban presentes tanto en la pared del cuerpo como en los tentáculos mientras que las varillas solo fueron observadas en los tentáculos orales. Estos últimos osículos, hasta donde se sabe, no han sido registrados antes para esta especie.

Euapta godeffroyi ha sido registrada en el océano Índico (Tanzania, Comoras, Aldabra, Madagascar,
Size: Approximately $80 \mathrm{~cm}$ long and between 2 to $3 \mathrm{~cm}$ in diameter.

Habitat: sandy-coral rubble bottom next to a coral patch of Pocillopora spp.

Locality and site of collection: Gorgona National Natural Park, El Arrecifito del Muelle.

The collected specimen (along with those observed in the field) showed the typical color and coloration pattern reported elsewhere (Semper, 1868; Granja-Fernández et al., 2013): greyish-brownish body with two visible yellow lines and a brown center on the dorsal region (Figure 2A). Those lines extend from the oral, where they are more intensely colored, to the aboral part. It seems, however, that the coloration intensity is variable at the intraspecific level. The tentacles, which are used for feeding, are creamy in color and pinnated. Under conditions of stress or danger, they are retracted into the body (Figure $2 \mathrm{~B}$ and $2 \mathrm{C}$ ). Euapta godeffroyi's body is extremely soft and flexible, which allows to shrink or extend its length and diameter several times. According to Brusca (1980), a specimen of around $30 \mathrm{~cm}$ in length, may reach up to $120 \mathrm{~cm}$ long when fully relaxed and extended. Finally, the body surface presents several rows of pouches-like formations, giving the appearance of corn (Figure 2).

The skeletal components of the body wall are mainly anchors with tiny ramifications at the base of the central axis and anchor plates with big perforations (Figure 3A, 3B, and 3C) and miliary granules. These types of ossicles have been already reported in different species of the family Synaptidae (Hendler et al., 1995; Borrero-Pérez et al., 2012). Two more types of ossicles were observed: one anchor-shaped with a smooth and pointing end (an early stage of the anchors) and another rod-shaped with forked branched ends (Figure 3D and 3E). It is important to note that anchors (either fully developed or in early stages) and plates were present in both the body wall and the tentacles while the rods were only observed in the oral tentacles. These last ossicles, as far as I know, have not been reported before for this species.

Euapta godeffroyi has been reported from the Indian Ocean (Tanzania, Comores, Aldabra, Madagascar, Seychelles, Republic of Mauritius, Mascarene Basin, and South Africa), the Red Sea (west coast of the Arabian Peninsula), the Central American Pacific Ocean (Panama and Costa Rica) (WoRMS, 2020), the Gulf of California (Mexico) (Kerstitch and Bertsch, 2007) and other localities 


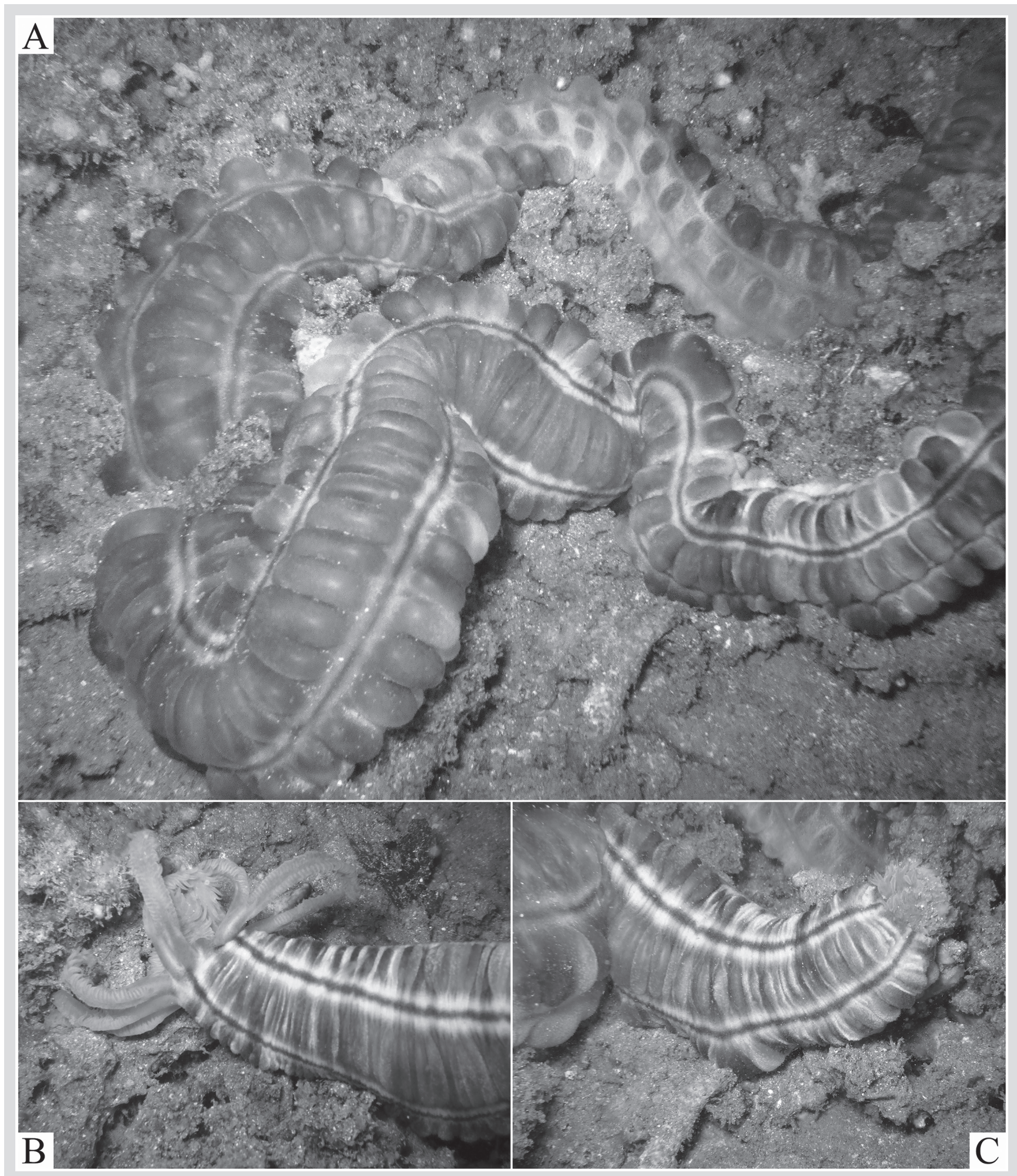

Figura 2. Euapta godeffroyi en su medio natural. A) Superficie de la pared del cuerpo en forma de maíz. B) y C) Tentáculos extendidos y retraídos, respectivamente.

Figure 2. Euapta godeffroyi in its natural environment. A) Corn-like surface of the body wall. B) and C) Extended and hidden tentacles, respectively.

Seychelles, Mauricio, la cuenca de Mascarene y Suráfrica), el mar Rojo (la costa oeste de la península Arábiga), el océano Pacífico centroamericano (Panamá y Costa Rica) along the Tropical Eastern Pacific (Granja-Fernández et al., 2013). It has also been reported from the Galápagos Islands (Ecuador) (Solís-Marín et al., 2013). In Colombia, 
A
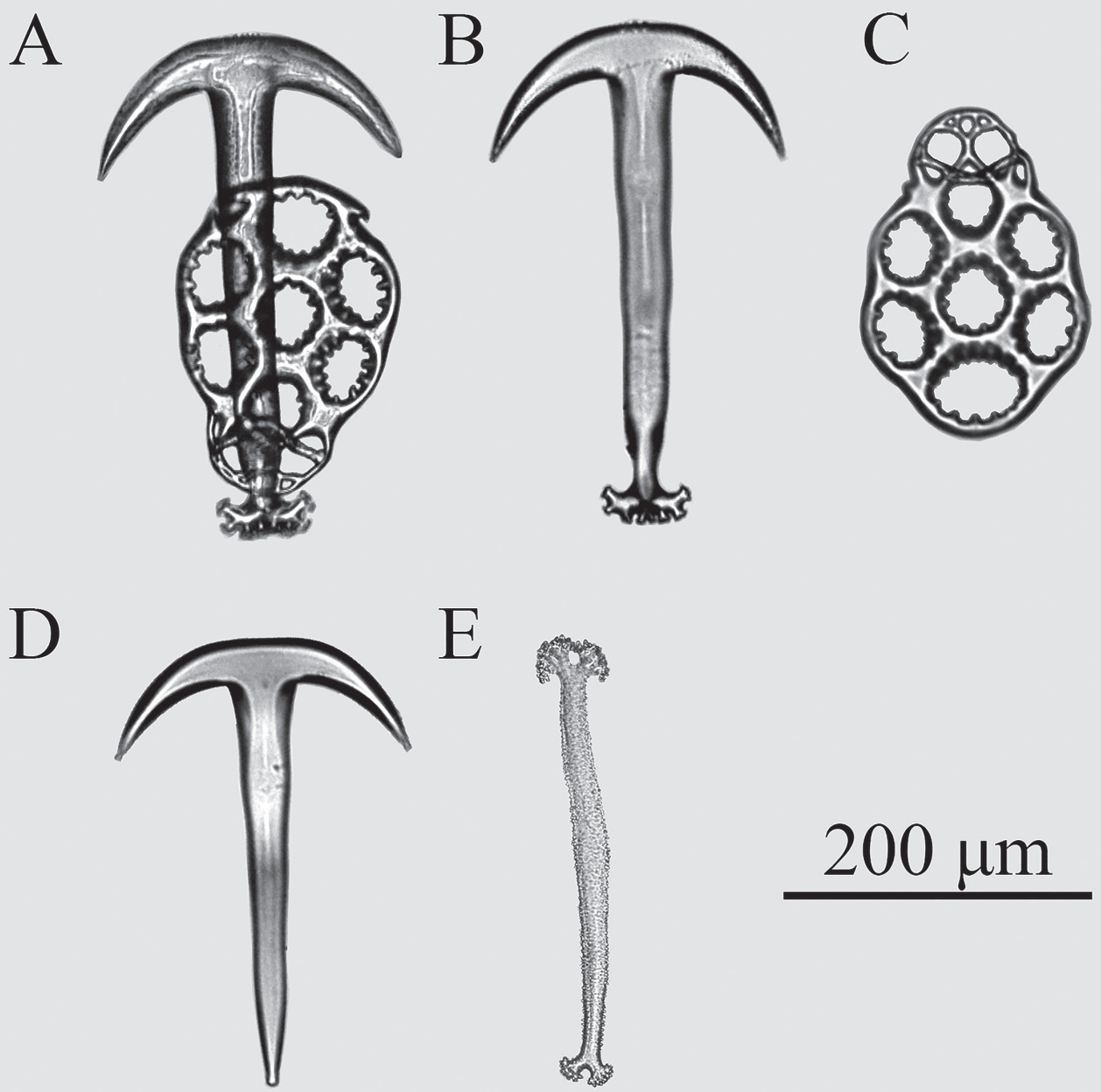

\section{$200 \mu \mathrm{m}$}

Figura 3. Osículos de Euapta godeffroyii. A) Ancla con placa. B) у C) Ancla común y placa separadas. D) Ancla en desarrollo con extremo puntudo. E) Varilla con extremos bifurcados (encontradas solo en los tentáculos orales).
Figure 3. Ossicles of Euapta godeffroyii. A) Anchor with plate. B) and C) Common anchor and plate separately. D) Developing anchor with a sharp tip. E) Rod with forked endings (found only in the oral tentacles).
(WoRMS, 2020), el golfo de California (México) (Kerstitch and Bertsch, 2007) y otras localidades a lo largo del Pacífico Oriental Tropical (Granja-Fernández et al., 2013). También ha sido registrado en las islas Galápagos (Ecuador) (SolísMarín et al., 2013). En Colombia, Benavides-Serrato et al. (2013) registran la presencia de esta especie, pero no dan ninguna referencia sobre la localidad o la fuente de información. Neira y Cantera (2005) registran 11 especies de holotúridos en la isla Gorgona, sin hacer ninguna referencia a $E$. godeffroyi. Benavides-Serrato et al. (2013) también registraron 11 especies de pepinos de mar para la misma localidad, de forma que es altamente probable que el registro no sea de la isla Gorgona. Otros autores que han trabajado con los equinodermos del Pacífico colombiano ( $e$. g. Neira et al., 1992; Cohen-Rengifo et al., 2009) tampoco
Benavides-Serrato et al. (2013) report the presence of this species, but they do not give any reference as to the locality or the source of information. Neira and Cantera (2005) report 11 species of holothurids on Gorgona Island, without making any reference to E. godeffroyi. Benavides-Serrato et al. (2013) also reported 11 species of sea-cucumbers for the same locality, so it is highly probable that the record is not from Gorgona Island. Other authors that have worked with the echinoderms of the Colombian Pacific (e.g. Neira et al., 1992; Cohen-Rengifo et al., 2009) have not reported this species either. Given the above, this is the first official record of E. godeffroyi in Gorgona Island and, perhaps, the first confirmed and documented in the Colombian Pacific, which fills a gap in the distribution of this species in the Eastern Tropical Pacific. 
han registrado esta especie. Dado lo anterior, este es el primer registro oficial de E. godeffroyi en la isla Gorgona y, quizás, el primero confirmado y documentado en el Pacífico colombiano, lo cual llena un vacío en la distribución de esta especie en el Pacífico Oriental Tropical.

Las primeras observaciones de E. godeffroyi en la isla Gorgona fueron en el año 1997 cuando un grupo de investigadores trabajó sobre el proceso de bioerosion en el arrecife de Playa Blanca. Más recientemente, esta especie fue vista en fondos de arena y cascajo coralino de parches arrecifales (El Muelle) y arrecifes de borde (La Azufrada y Playa Blanca), durante buceos nocturnos. E. godeffroyi es activo en la noche cuando sale de su refugio para alimentarse. Este comportamiento ha sido registrado por otros autores (Brusca, 1980; Kerstitch and Bertsch, 2007; Granja-Fernández et al., 2013). Durante el día, normalmente está escondido en grietas o bajo la matriz arrecifal, presumiblemente para protegerse. Al menos en la isla Gorgona, nunca ha sido visto exponiéndose durante el día. Este pepino muestra reacciones variadas cuando se perturba: usualmente se encoje, pero, si es manipulado, puede extenderse significativamente. El espécimen recolectado se estaba alimentando con cascajo coralino y colonias sueltas de Pocillopora sp.

\section{AGRADECIMIENTOS}

Se agradece profundamente al Dr. Ranulfo González y a la bióloga Lina María Prieto-Martínez por su invaluable ayuda con las fotos de los osículos. El espécimen fue recolectado mientras se realizaba trabajo de campo asociado al proyecto "Evaluación del estado actual de los objetos de conservación faunísticos en isla Gorgona: una aproximación holística a la valoración ecológica del PNN Gorgona", financiado por Conservación Internacional y el Fondo para la Acción Ambiental y la Niñez. Contribución 16 del Instituto de Ciencias del Mar y Limnología (Incimar) de la Universidad del Valle.
The first sightings of E. godeffroyi at Gorgona Island were in 1997 when a group of researchers was working on the bioerosion process at Playa Blanca reef. More recently, this species was seen on coral rubble-sandy bottoms of reef patches (El Muelle) and fringing reefs (La Azufrada and Playa Blanca) during night dives. Euapta godeffroyi is active at night when it goes out from cover to feed. This behavior has been reported elsewhere (Brusca, 1980; Kerstitch and Bertsch, 2007; Granja-Fernández et al., 2013). During the daytime, it is normally hidden in crevices or under the reef matrix, presumably for protection. At least, in Gorgona Island, it has never been observed exposed during the daytime. This sea-cucumber shows several different reactions when disturbed, usually, it shrinks, but if handled, it can extend significantly. The collected specimen was feeding between coral rubble and loosely dispersed Pocillopora sp. coral colonies.

\section{ACKNOWLEDGMENTS}

The author is deeply indebted to Dr. Ranulfo González and the biologist Lina María Prieto-Martínez for their invaluable help with the ossicles pictures. The specimen was collected while in a sampling trip of the research project "Evaluación del estado actual de los objetos de conservación faunísticos en Isla Gorgona: una aproximación holística a la valoración ecológica del PNN Gorgona" funded by Conservation International and Fondo para la Acción Ambiental y la Niñez. Contribution 16 from the Universidad del Valle's Institute of Marine Sciences and Limnology (Incimar).

\section{BIBLIOGRAFÍA/LITERATURE CITED}

Alvarado, J.J. and F.A. Solís-Marín. 2013. Echinoderm research and diversity in Latin America. Berlin, Springer. 658 p.

Benavides-Serrato, M., G.H. Borrero-Pérez, J.R. Cantera, M. Cohen-Rengifo, and R. Neira. 2013. Echinoderms of Colombia. 145-182. In: Alvarado, J.J. and F.A. Solís-Marín. (Eds.). Echinoderm research and diversity in Latin America. Berlin, Springer. 658 p.

Borrero-Pérez, G.H., M. Benavides-Serrato y C.M. Díaz-Sánchez. 2012. Equinodermos del Caribe colombiano II: Echinoidea y Holothuroidea. Ser. Publ. Espec. Invemar, (30), $250 \mathrm{p}$.

Brusca, R.C. 1980. Common invertebrates of the Gulf of California. 2nd Ed. Univ. Arizona, Tucson. 513 p. 
Cohen-Rengifo, M., S. Bessudo, and G. Soler. 2009. Echinoderms, Malpelo Fauna and Flora Sanctuary, Colombian Pacific: new reports and distributional issues. CheckList, 5(3):702-711.

Granja-Fernández, R., V. Antonio-Pérez, and R.A. López-Pérez. 2013. Euapta godeffroyi (Holothuroidea: Synaptidae): filling the distribution gap between Mexico and Costa Rica, Eastern Tropical Pacific. Hidrobiológica, 23(1): 130-132.

Hendler, G., J.E. Miller, D.L. Pawson, and K.M. Porter. 1995. Sea stars, sea urchins, and allies: echinoderms of Florida and the Caribbean. Smithsonian Inst. Press, Washington. 390 p.

Kerstitch, A. and H. Bertsch. 2007. Sea of Cortez marine invertebrates. A guide for the Pacific coast, México to Perú. 2nd ed. Sea Challengers, Monterey, USA. 124 p.

Londoño-Cruz, E., L.D. Obonaga, and M. Zucconi-Ramírez. 2018. First record of Echinothrix calamaris (Echinoidea: Diadematidae) in the Colombian Pacific. Mar Biod. Rec., 11: 15. https://doi.org/10.1186/s41200-018-0150-5

Muñoz, C.G. and E. Londoño-Cruz. 2016. First record of the irregular sea urchin Lovenia cordiformis (Echinodermata: Spatangoida: Loveniidae) in Colombia. Mar Biod. Rec., 9: 67. https://doi.org/10.1186/s41200-016-0022-9.

Neira, R. y J.R. Cantera. 2005. Composición taxonómica y distribución de las asociaciones de equinodermos en los ecosistemas litorales del Pacifico Colombiano. Rev. Biol. Trop., 53(3): 195-206.

Neira, R., P. Barba y R. Pardo. 1992. Equinodermos del Parque Nacional Natural Ensenada de Utria (Pacífico colombiano). An. Inst. Invest. Mar. Punta Betín, 21: 77-83.

Pawson, D.L. 2007. Phylum Echinodermata. Zootaxa, 1668: 749-764.

Roskov, Y., G. Ower, T. Orrell, D. Nicholson, N. Bailly, P.M. Kirk, T. Bourgoin, R.E. DeWalt, W. Decock, E. Nieukerken, J. van Zarucchi, and L. Penev (Eds.). 2019. Species 2000 \& ITIS Catalogue of Life, 2019 Annual Checklist. http://www.catalogueoflife.org/annual-checklist/2019.

Semper, C. 1868. Reisen im Archipel der Philippinen. Holothurien. 2.Wissenschaftliche Resultate. Verlag von Wilhelm Engelmann, Leipzig. 288 p.

Solís-Marín F.A., J.J. Alvarado, M. Abreu-Pérez, O. Aguilera, J. Alió, J.J. Bacallado-Aránega, E. Barraza, M. Benavides-Serrato, et al. 2013. Appendix. 543658. In: Alvarado, J.J. and F.A. Solís-Marín. (Eds.). Echinoderm research and diversity in Latin America. Springer-Verlag, Berlin. 658 p.

WoRMS. 2020. Euapta godeffroyi (Semper, 1868). http://www.marinespecies.org/aphia.php?p=taxdetails\&id=210968. 2020-06-25.

Zhang, Z.-Q. 2013. Animal biodiversity: an update of classification and diversity in 2013. In: Zhang, Z.-Q. (Ed.). Animal biodiversity: an outline of higherlevel classification and survey of taxonomic richness (Addenda 2013). Zootaxa, 3703: 1-82.

RECIBIDO/RECEIVED: 21/07/2020

ACEPTADO/ACCEPTED: 28/09/2020 